УДК 339.138

doi: 10.15330/apred.2.17.87-94

\title{
ЦИФРОВИЙ МАРКЕТИНГ БАНКІВСЬКИХ ПОСЛУГ: ЗМІНИ В ПЕРІОД ПАНДЕМІї
}

\author{
${ }^{1}$ Національний університет «Львівська \\ політехніка», \\ Міністерства освіти і науки України, \\ кафедра маркетингу і логістики, \\ вул. Митрополита Андрея, 5, м. Львів, \\ 79000, Україна, \\ тел.: +380636151142, \\ e-mail: Nadiia.M.Vasyltsiv@lpnu.ua, \\ ORCID: 0000-0002-4127-2163
}

\begin{abstract}
Анотація. В статті доведено необхідність використання цифрового маркетингу в банківській діяльності. Досліджено використання банківських послуг в період пандемії. Метою даної статті є висвітлення наукових підходів щодо зміни підходів до цифрового маркетингу банківських послуг в період пандемії. В процесі написання статті використано ряд загальнонаукових та спеціальних методів дослідження. Зокрема індуктивний, дедуктивний методи застосовано при зборі, обробці даних щодо кількості діючих банків; економічний аналіз та порівняння використано при формуванні рейтингу стійкості банків; графічний метод та метод економіко-математичного моделювання застосовано для наочного відображення та розрахунку прогнозних показників зростання/зменшення кількості банків за лінійною та поліноміальною функцією. Для теоретичних узагальнень і формування висновків використано абстрактно-логічний метод. Встановлено динаміку скорочення кількості банків як іноземних так і приватних за 2017-2020p. Доведено аналогічну тенденцію на майбутні 3-4 роки 3 використанням лінійної та поліноміальної функції, де коефіцієнт детермінації $\mathrm{R}^{2}$, за лінійною функцією дорівнює 0,8325 , та за поліноміальною функцією - 0,8896, що свідчить про вірність моделі. Обгрунтовано, що найвищу позицію в рейтингу стійкості банків посідає Райфайзен Банк, який залишається лідером із якості обслуговування в українському банківському секторі. Перевагами Райфайзен Банк $є$ широкий перелік стандартних та інноваційних послуг (зарплатні, приватні та пенсійні платіжні картки, Інтернет-банкінг, депозити, кредити та інші) та наявність близько 3 млн клієнтів. Обгрунтовано, що для підвищення конкурентних позицій на ринку банки повинні модифікувати свої послуги в період пандемії. Виникає необхідність у використанні банками інноваційних технологій таких як віртуальна реальність, використання платформи інтернет банкінгу, запровадження послуги «кредитні канікули» та використання технології віртуальної і доповненої реальності. Доведено, що віртуальні технології вирішують відразу кілька завдань: $є$ маркетинговим інструментом, вирішують завдання відділу продажів, служать комунікативним та інформаційним каналами.
\end{abstract}

Ключові слова: цифровий маркетинг, банківські послуги, пандемія, банки, рейтинг стійкості банків.

DIGITAL MARKETING OF BANKING SERVICES: TRANSFORMATIONS IN THE PANDEMIC PERIOD

\footnotetext{
${ }^{1}$ Lviv Polytechnic National University, Department of Marketing and Logistics Metropolitan Andrew str., 5, Lviv, 79000, Ukraine,
} 
Abstract. The article substantiates the necessity of using digital marketing in banking activity. Banking services are studied in the pandemic period. The goal of the article is to present the scientific approaches to studying transformations in digital marketing of banking services in the pandemic period. Preparation of the current article involved applying a set of general scientific and special methods of research. In particular, inductive and deductive methods were used for collecting and processing of data concerning the number of operating banks; economic analysis and comparison were applied to compose the bank stability rating; graphic method and method of economic and mathematical modeling - for visual presentation and calculation of the expected indices of increase/decrease of the number of banks by the linear and polynomial functions; abstract and logical method - for theoretical generalization and conclusion making. The research confirms the reduction dynamics in the number of banks, both foreign and private in the period of 2017-2020. The similar tendency is expected in the next 3-4 years that is justified by the linear and polynomial functions, where the determination factor $\mathrm{R}^{2}$ is equal to 0.8325 by the linear function, and 0.8896 by the polynomial function that confirms the model reliability. It is substantiated that the highest position in the rating of banks' stability is occupied by Raiffeisen Bank, which remains the leader in the quality of service in the Ukrainian banking sector. The advantages of Raiffeisen Bank are a wide range of standard and innovative services (salary, private and pension payment cards, Internet banking, deposits, loans, etc.) and the presence of about 3 million customers. To improve the competitive positions at the market, banks should modify their services in the pandemic period. Therefore, it is necessary for the banks to use innovative technologies like virtual reality, Internet banking platform, introduction of "payment holidays" services, and use of technologies of virtual and augmented reality. It is substantiated that virtual technologies solve several problems, namely they act as marketing instruments, they solve the tasks of sale departments, they serve as communication and information channels.

Key words: digital marketing, banking services, pandemic, banks, bank stability rating.

Вступ. Цифровий маркетинг є однією з найбільш гнучких сфер бізнесу, оскільки саме від нього залежать обсяги продажу продукції. Цифровий маркетинг став надзвичайно популярним, особливо в умовах пандемії, коли переважна більшість підприємств перейшли на онлайн продажі. Особливої актуальності набирають дослідження використання цифрового маркетингу в банківській сфері. Питання комплексної організації системи цифрового маркетингу, його реалізації комерційними банками на основі нововведень 3 просування банківських продуктів і послуг на фінансовий ринок, а також обгрунтування каналів доставки їх до споживачів. Тому тема дослідження $\epsilon$ актуальною, оскільки визначає необхідність оптимізації організаційної структури послуг комерційного банку на основі комплексної реалізації системи цифрового маркетингу.

В сучасних умовах розвитку діджиталізації цифровий маркетинг є предметом підвищеної зацікавленості вітчизняних підприємств. Це дане питання ще не достатньо вивченим вченими та практиками, хоче $\epsilon$ й певні напрацювання в даній сфері. Бочко О.Ю. обгрунтовувала теоретичні аспекти електронного маркетингу [3]. Окландер М. А., Романенко О.О. вказували на специфічні відмінності цифрового маркетингу від Інтернет-маркетингу [9].

Цифровий маркетинг Карпіщенко О. О., Логінова Ю. Е. розглядали з точки зору інноваційного інструменту комунікацій [5], а Марчук О.О. - як інноваційний інструмент управління [6]. Проте в більшості наукових праць розкрито теоретичні підходи до цифрового маркетингу. Недостатньо досліджень, які б розкривали особливості цифрового маркетингу в окремих сферах, зокрема в банківській. Водночас 
багато напрацювань вітчизняних вчених, які стосуються дослідження маркетингу в банківській діяльності, інакше його називають банківський маркетинг.

Одними із перших науковців, хто почав досліджувати банківський маркетинг в Україні, були І. О. Спіцин і Я. О. Спіцин. У своїй праці 1993 р., не пропонуючи формулювання поняття «банківський маркетинг», вони відзначають, що «...маркетингова діяльність у банку принципово не відрізняється від маркетингу в промисловості, але має ряд особливостей, обумовлених специфікою банківської діяльності» [13]. Даний підхід дещо звужує дослідження банківського маркетингу

Брітченко І.Г. стверджує, що банківський маркетинг - це стратегія і філософія банку, що вимагає ретельної підготовки, глибокого і всебічного аналізу, активної роботи всіх підрозділів банку від керівників до низових ланок [4]. Нікітін А. В., Іванова Т. Г., Брітченко I. Г., Момот О. М. (автори праці «Маркетинг у банку») зазначали, що «банківський маркетинг - це процес, який включає дослідження фінансового ринку та ринку банківських послуг, планування виробництва, налагодження системи комунікації 3 цільовим ринком і організацію просування банківських продуктів» [8].

Разом $з$ тим , що банківський маркетинг - це діяльність банківських структур, направлена на розширення їх сегменту, забезпечення ринку новими існуючими послугами 3 метою підвищення прибутків [15]. Вже в подальших роботах автори доводять, що маркетинг банківських послуг має двоєдину мету - забезпечити максимальний прибуток банку та задовольнити попит споживачів за мінімальних ризиків.

Отже, можемо спостерігати достатню кількість наукових праць, які стосуються банківського маркетингу та цифрового маркетингу, проте недостатньо напрацювань, які поєднують ці дві сфери діяльності. Відтак виникає необхідність подальших досліджень цифрового маркетингу в сфері банківських послуг в період пандемії, що переводить його в онлайн платформу.

Постановка завдання. Метою даної статті є висвітлення наукових підходів щодо зміни підходів до цифрового маркетингу банківських послуг в період пандемії. В процесі написання статті використано ряд загальнонаукових та спеціальних методів дослідження. Зокрема для збору, обробки даних щодо кількості діючих банків використано індуктивний, дедуктивний методи. За допомогою економічного аналізу та порівняння здійснено рейтинг стійкості банків. Графічний метод та метод економікоматематичного моделювання використано для наочного відображення та розрахунку прогнозних показників зростання/зменшення кількості банків за лінійною та поліноміальною функцією. Для теоретичних узагальнень і формування висновків використано абстрактно-логічний метод.

Результати. Банківська діяльність в період пандемії знаходиться під прицілом як клієнтів/споживачів так і державних органів. Від рівня розвитку банківської системи, іiі ресурсного потенціалу, надійності та високого рівня платоспроможності залежить забезпеченість фінансовими ресурсами всіх галузей економіки.

За 2017-2020p. переважна скоротилася кількість банків як іноземних так i приватних (табл. 1), хоча за останні 6 місяців 2021р. їх кількість порівняно з 2020p. не зазнала змін. 
Кількість діючих банків*

Таблиияя 1

Table 1

Number of operating banks *

\begin{tabular}{|c|c|c|c|c|c|c|}
\hline Види банків & 2017p. & 2018p. & 2019p. & 2020p. & 6м 2021p.** & $\begin{array}{c}\text { Відхилення } \\
\text { 2020p. до } \\
2017 \mathrm{p} .\end{array}$ \\
\hline Платоспроможні & 82 & 77 & 75 & 73 & 73 & 89,0 \\
\hline Державні & 5 & 5 & 5 & 5 & 5 & 100,0 \\
\hline Іноземні & 23 & 21 & 20 & 20 & 20 & 87,0 \\
\hline Приватні & 54 & 51 & 50 & 48 & 48 & 88,9 \\
\hline
\end{tabular}

* Кількість наведено на кінець відповідного періоду

Без змін залишається кількість державних банків: Ощадбанк, Приватбанк, Розрахунковий центр, Укргазбанк, Укрсімбанк. Обсяги загальних активів за квартал зросли на 1.6\%, найвищі темпи були у приватних банків. Державні банки продовжували списувати зарезервовані непрацюючі кредити, у них загальні активи скорочувалися.

Важливо розуміти, що на майбутній період кількість банків не буде зростати, про що свідчать дані рис.1.

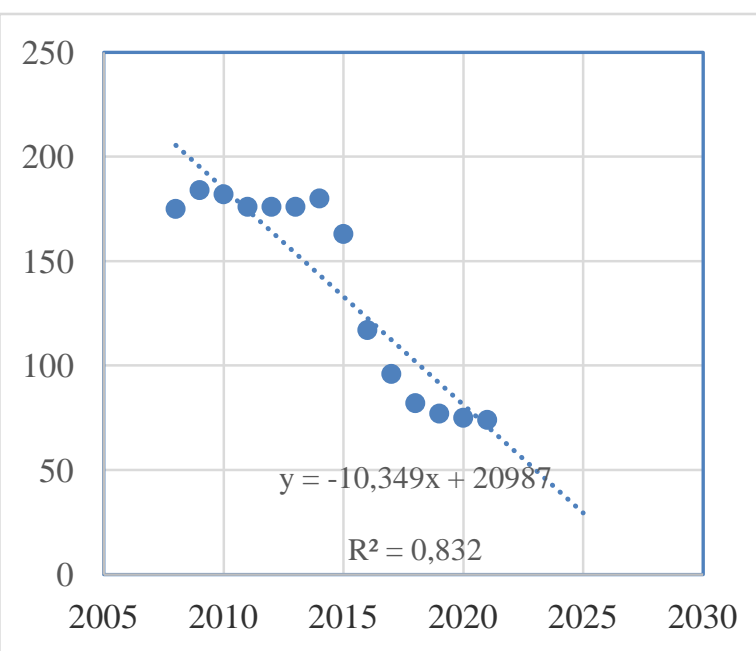

Лінійна функція

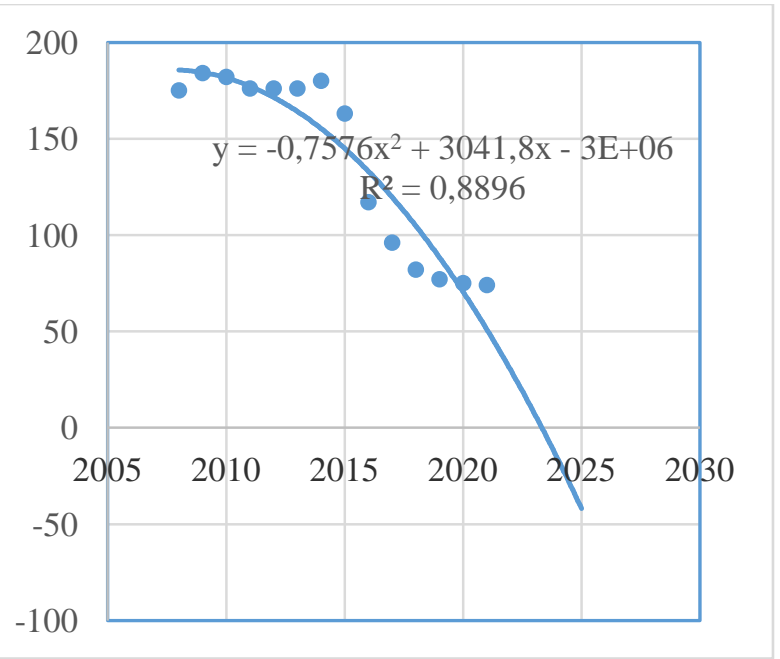

Поліноміальна функція

Puc. 1. Прогнозні показники зменшення кількості банків за лінійною та поліноміальною функцією

Fig. 1. Expected indices of reduction in the number of banks by linear and polynomial functions

За результатами нашого дослідження коефіцієнт детермінації $\mathrm{R}^{2}$, за лінійною функцією дорівнює 0,8325, та за поліноміальною функцією - 0,8896, що свідчить про вірність моделі.

Скорочення кількості банків викликане :

по-перше, масштабною чисткою системи, яку проводить НБУ;

по-друге, скороченням кількості відділень через окупацію української території;

по-третє, рівень економічної активності, який характеризується реальним наявним доходом; 
Актуальні проблеми розвитку економіки регіону. Вип 17. Т.2

по-четверте, розвитком онлайн технологій, що дозволяє перевести банківські платежі на ринок інтернет-банкінгу. Хоча Д. Остапчук доводить, «кореляція між кількістю відділень і проникненням інтернету негативна (-36\%)». «Регресійний аналіз не показав значимої математичної залежності між проникненням інтернету, реальним наявним доходом і кількістю відділень. Це пояснюється тим, що на число відділень можуть впливати й інші чинники: кількість міського населення, число підприємств, їхній розмір», - доводить автор статті [9].

Для банківської сфери важливе значення має стабільність. Основним показником, який визначає рівень стабільної банківської системи є рівень стійкості. Цей показник $є$ запорукою успіху економічних перетворень і макроекономічного розвитку. «Оцінка фінансової стійкості являє собою досить складний та не завжди достовірний процес, оскільки потребує визначення максимально реальних показників діяльності установи» доводить В. В. Рисін [11]. Міністерством фінансів України сформовано рейтинг стійкості українських банків, який представлено в табл. 2.

Таблиия 2

Рейтинг стійкості банків (станом на 2 квартал 2021р.)*

Table 2

Bank stability rating (as of the $2^{\text {nd }}$ quarter 2021) *

\begin{tabular}{|c|c|c|c|c|}
\hline \multirow{2}{*}{$\begin{array}{l}\text { № } \\
\Pi / \Pi\end{array}$} & \multirow[t]{2}{*}{ Назва банку } & \multirow{2}{*}{$\begin{array}{c}\text { Загальний } \\
\text { рейтинг }\end{array}$} & \multicolumn{2}{|c|}{3 них: } \\
\hline & & & $\begin{array}{l}\text { Лояльність } \\
\text { вкладників }\end{array}$ & $\begin{array}{c}\text { Оцінка } \\
\text { аналітиків }\end{array}$ \\
\hline 1 & Райфайзен Банк & 4,54 & 4,2 & 4,8 \\
\hline 2 & Креді Агріколь Банк & 4,19 & 4 & 4,1 \\
\hline 3 & Укрсиббанк & 4,16 & 3,5 & 4,6 \\
\hline 4 & Кредобанк & 4,03 & 3,8 & 4,3 \\
\hline 5 & ОТП Банк & 4,00 & 4,1 & 3,6 \\
\hline 6 & Альфі-Банк & 3,82 & 3,2 & 4,4 \\
\hline 7 & Правекс Банк & 3,74 & 3,6 & 3,9 \\
\hline 8 & ПУМБ & 3,61 & 3 & 4,2 \\
\hline 9 & Укргазбанк & 3,61 & 3,3 & 3,5 \\
\hline 10 & Приватбанк & 3,59 & 3,2 & 3,6 \\
\hline
\end{tabular}

*За даними [16]

Отже, за даними порталу «Мінфін» найвищу позицію в рейтингу стійкості банків посідає Райфайзен Банк, який залишається лідером із якості обслуговування в українському банківському секторі. Банк підвищує якість обслуговування клієнтів, використовуючи власний досвід та досвід інших дочірніх банків групи «Райффайзен Банк Інтернаціональ», а також використовує новітні технології. Банк надає широкий перелік стандартних та інноваційних послуг (зарплатні, приватні та пенсійні платіжні картки, Інтернет-банкінг, депозити, кредити та інші) та має близько 3 млн клієнтів через власну мережу відділень, центрів самообслуговування та банкоматів по всій Україні.

Відтак 3 метою отримання конкурентних позицій на ринку банки повинні модефікувати свої послуги. Зокрема окремі з них запропонували зміни під час пандемії. Наприклад, під час карантину можна онлайн пролонгувати банківські довіреності до поточного рахунку:

- за допомогою інтернет-банкінгу MyBank;

- за допомогою чат-бота у Viber, Telegram, Messenger Facebook;

- на сайті банку [13]. 
Продовження терміну дії договору оренди (у тому числі за договорами, термін дії яких минув) здійснюється шляхом подання заявки на за допомогою MyBank або чатбота. При цьому необхідно повідомити номер i дату договору оренди, строк продовження договору оренди, номер свого рахунку (у гривнях) для списання грошових коштів за продовження.

У період карантину Національний банк запропонував «кредитні канікули» особливий пільговий період обслуговування кредитів для населення та бізнесу в період дії карантину та після його завершення [6]. Ці заходи Нацбанк рекомендує всім банківським установам, щоб допомогти позичальникам, які постраждали від поширення коронавируса і введення надзвичайних ситуацій та карантину.

Перша частина пільгових умов - це відстрочка платежів по кредиту. Позичальники можуть платити їм після закінчення карантину, а банки не накладають штрафи або пені за прострочення платежу. Однак позичальникам необхідно розуміти, що це не списання боргу, а відстрочка платежу і відсотків за позикою. Відсотки продовжують нараховуватися під час карантину і повинні бути виплачені після карантину.

Друга частина пільгових умов - це заходи щодо полегшення погашення i обслуговування боргів після закінчення карантину. Відтак банки активно пропонували реструктуризацію кредитів.

В період карантину банки запропонували громадянам, індивідуальним підприємцям і власникам малого бізнесу зміну графіків платежів, звільнення від кредиту на період карантину 3 відповідним продовженням кредиту, капіталізацію процентних виплат Для середніх i великих компаній банки використовують індивідуальні підходи в залежності від фінансового становища компанії і того, наскільки сильно компанія постраждала від карантину.

Більшість банків сьогодні готові запропонувати новий набір послуг і продуктів. Щоб виділитися на тлі конкурентів і залучити клієнтів, компаніям доводиться вигадувати щось унікальне. Банки вдаються до використання інноваційних інструментів. Один з них - технології віртуальної і доповненої реальності. Часто при цьому VR / AR-технології вирішують відразу кілька завдань: $\epsilon$ маркетинговим інструментом, вирішують завдання відділу продажів, служать комунікативним та інформаційним каналами.

В сучасних умовах банки досить часто використовують віртуальну реальність. У VR-форматі можна демонструвати клієнтам інформаційний ролик про особливості технології блокчейн. $€$ можливість наочного пояснення складних процесів через прості образи і приклади дозволяє клієнтам розібратися в роботі технології. Формат повного занурення також сприяє концентрації уваги і підвищує у глядача інтерес до нової інформації.

Загалом віртуальні консультанти поки що не здатні повністю витіснити людей i замінити реальних працівників, але передумови до цього є. У 2019 Національний банк Шанхая перевів співробітників одного зі своїх відділень працювати ... в віртуальну реальність. Консультанти за допомогою VR-окулярів спілкуються 3 клієнтами i займаються оформленням банківських послуг, видачею кредитів так, як це могло б відбуватися в реальному житті. Проект працює до цих пір і, за словами керівництва банку, він дуже ефективний. Недолік подібного рішення полягає в невеликій поширеності VR-пристроїв. Тому такі проекти важливо було б адаптувати під інші пристрої - смартфони, планшети, ПК [10].

Висновки. Цифровий маркетинг відіграє важливу роль в банківській діяльності, хоча кількість банків і зменшується з кожним роком. За 2017-2020рр. кількість банків скоротилася на 11\%. Така тенденція прогнозується також ра майбутні 3-4 роки, про що 
свідчать прогнозні показники зменшення кількості банків за лінійною та поліноміальною функцією. Банківська діяльність в період пандемії змінює свої підходи. Виникає необхідність у використанні інноваційних технологій таких як віртуальна реальність, використання платформи інтернет банкінгу, запровадження послуги «кредитні канікули» та використання технології віртуальної і доповненої реальності.

Наукова новизна статті полягає у формуванні нових підходів до поширення цифрового маркетингу банківських послуг в період пандемії.

Теоретичне та практичне значення статті виявлення теоретичних підходів до цифрового маркетингу банківських послуг в період пандемії.

Перспективами подальших розвідок в даному напрямі $\epsilon$ вивчення впливу маркетингових комунікацій на поширення послуг в інтернет-банкінгу.

1. Балабанова Л.В. Маркетинг : підручник [вид. 3-е, перероблене та доповнене]. Донецьк : ДонНУЕТ, 2012. T. $1.348 \mathrm{c}$.

2. Бочко О. Ю. Еволюція розвитку концепцій інтернет-маркетингу. Маркетинг і иифрові технології: 3б. Матеріалів III Міжнар. наук-прак. конф. 25-26 травня 2018р., Одеса : ТЕС, 2018. С. 55-56.

3. Бочко О. Ю. Електронний маркетинг сучасності. Вісник Львівського наиіонального аграрного університету: економіка АПК. 2013. №20 (2). С. 65-68.

4. Брітченко І. Г., Бєлявцев М. І., Тягунова Н. М. Маркетинг у банках: Навчальний посібник / Під ред. проф. Брітченко І.Г. Полтава: РВВ ПУСКУ, 2008. 345 с.

5. Карпіщенко О. О., Логінова Ю. Е. Цифровий маркетинг як інноваційний інструмент комунікацій. Економічні проблеми сталого розвитку : матеріали доповідей Міжнародної науково-практичної конференції, присвяченої 20-річчю наукової діяльності ф-ту економіки та менеджменту СумДУ, м. Суми, 3-5 квітня 2012 р. / Відп. за вип. О.В. Прокопенко. Суми : СумДУ, 2012. Т.5. С. 177-178.

6. Марчук О.О. Цифровий маркетинг як інноваційний інструмент управління. Економіка $i$ суспільство. 2018. Вип. 17. С. 296-299.

7. Надання банківських послуг під час карантину http://www.kradmin.gov.ua/start.php?q=Aktualno/Ua/1404201/14042001.html (дата звернення: 21.09.2021).

8. Нікітін А. В., Іванова Т. Г., Брітченко І. Г., Момот О. М. Маркетинг у банку: навч. метод. посіб. для самостійного вивч. дисц. К. : КНЕУ, 2010. 474 с.

9. Окландер М. А., Романенко О.О. Специфічні відмінності цифрового маркетингу від Інтернетмаркетингу. Економічний вісник Національного технічного університету України «Київський політехнічний інститут». 2015. № 12. С. 362-371.

10. Остапчук Д. Знеструмлені мережі: хто винен у 50-відсотковій дефляції банків. URL: https://www.epravda.com.ua/publications/2016/07/21/599876/ (дата звернення 21.09.2021).

11. Подплетько К. Как банки используют VR/AR технологии? https://modumlab.com/blog/banking (дата звернення: 21.09.2021).

12. Рисін В. В. Біда А. П. Фінансова стійкість банку: чинники та особливості забезпечення. Ефективна економіка. http://www.economy.nayka.com.ua/pdf/3_2021/3.pdf (дата звернення: 21.09.2021).

13. Спицын И. О., Спицын Я. О. Маркетинг в банке. Тернополь : АО «Тарнекс»; К. : ЦММС «Писпайп», 1993. 656 c.

14. Які нові банківські послуги доступні клієнтам дистанційно під час карантину? https://bank.com.ua/news/yaki-novi-bankivski-poslugi-dostupni-kliyentam-distanciyno (дата звернення: 21.09.2021).

15. Янковська Л.А, Семчук Ж.В., Харук К.Б., Бочко О.Ю., Скриньковський Р.М. Банківський маркетинг : навч. посібн. Львів «Галицька видавнича спілка», 2016. 224 с.

16. Frost Steven M. (2013). Desk book of banking Analyst: the money, the risks and the professional techniques. Dnipropetrovsk, 672 p

17. Minfin. URL: https://minfin.com.ua/ (дата звернення: 21.09.2021).

\section{References}

1. Balabanova, L. Marketing: schoolbook. Donetsk: DonNUET, 2012.

2. Bochko, O. Yu. "Evolution of development of concepts of Internet marketing." Marketing and Digital Technology: Sb. Material III Mizhnar. Sciences-Prak Conf. May 25-26. Odessa, TPP, 2018, pp 55-56.

3. Bochko, O. Yu. "Electronic marketing of the present." Visnyk of Lviv National Agrarian University: Economy of Agroindustrial Complex, no. 20 (2), 2013, pp. 65-68.

4. Britchenko, I.H., Bieliavtsev, M.I., and N.M.Tiahunova. Marketing in banks: textbook, ed. by Britchenko I.H. Poltava, RVV PUSKU, 2008. 
5. Karpishchenko, O.O., and Yu.E.Lohinova. "Digital marketing as an innovative instrument of communication." Economic problems of sustainable development: proceedings of the International scientific and practical conference, devoted to the 20thh anniversary of the Faculty of Economics and Management of SumySU, Sumy, 3-5 April 2012. Sumy, SumySU, vol. 5, 2012, pp. 177-178.

6. Marchuk, O.O. "Digital marketing as an innovative instrument of management." Economics and society, Issue 17, 2018., pp. 296-299.

7. "Supply of banking services during the quarantine." Kirovogradske oblasna administratsiia, www.kradmin.gov.ua/start.php?q=Aktualno/Ua/1404201/14042001.html. Accessed 21 Sept. 2021.

8. Nikitin, A.V., Ivanova, T.H., Britchenko, I.H., and O.M.Momot. Marketing in banks: scientific and methodic manual for self-studying of discipline. Kyiv, KSEU, 2012.

9. Oklander M. A., and O.O.Romanenko. "Specific differences in digital marketing from internet marketing." Economic Bulletin of the National Technical University of Ukraine "Kyiv Polytechnic Institute”, no. 12, 2015, pp. 362-371.

10. Ostapchuk, D. "Unplugged networks: who is guilty of 50-percent deflation of banks. Epravda, www.epravda.com.ua/publications/2016/07/21/599876/ Accessed 21 Sept. 2021.

11. Podpletko, K.”How VR/AR technologies are used by banks?” Modumlab, modumlab.com/blog/banking. Accessed 21 Sept. 2021.

12. Rysin, V.V., and A.P. Bida. "Financial stability of banks: factors and peculiarities of supply." Efficient economics, www.economy.nayka.com.ua/pdf/3_2021/3.pdf. Accessed 21 Sept. 2021.

13. Spitsyn, I.O., and Ya.O.Spitsyn. Marketing in banks. Ternopol, JSC “Tarneks”; Kyiv, CMMS “Pispaip”, 1993. .

14. "What new banking services are available online for the customer during the quarantine?”. Bank Pivdennyi, bank.com.ua/news/yaki-novi-bankivski-poslugi-dostupni-kliyentam-distanciyno. Accessed 21 Sept. 2021..

15. Yankovska, L.A., Semchuk, Zh.V., Kharuk, K.B., Bochko, O.Yu., and R.M.Skrynkoskyi. Banking marketing: textbook. Lviv "Halytska vydavnycha spilka”, 2016.

16. Frost, Steven M. Desk book of banking Analyst: the money, the risks and the professional techniques. Dnipropetrovsk, 2013

17. Minfin, minfin.com.ua. Accessed 21 Sept. 2021.

\section{УДК 656.07}

doi: 10.15330/apred.2.17.94-108

\section{Клименко В.В. ${ }^{1}$, Лозова Г.М. ${ }^{2}$ ЕФЕКТИВНІСТЬ ДІЯЛЬНОСТІ ПІДПРИЕМСТВ НА РИНКУ ЛОГІСТИЧНИХ ПОСЛУГ В УКРАЇНІ}

\footnotetext{
${ }^{1}$ Національний авіаційний університет, Міністерство освіти і науки України, кафедра організації авіаційних робіт та послуг, пр. Гузара Любомира, 1, м. Київ, 03058, Україна, тел.: +38 (097) 2092813, e-mail: klymenko_viktoriya@nau.edu.ua, ORCID: 0000-0002-4168-3296

${ }^{2}$ Київський національний університет імені Тараса Шевченка, Міністерство освіти і науки України, кафедра економічної теорії, макро- і мікроекономіки, вул. Володимирська, 60, м. Київ,
} 